\title{
KEADILAN DALAM PEMILU BEDASARKAN SISTEM PRESIDENSIAL THRESHOLD
}

\author{
Dian Fitri Sabrina, Muhammad Saad \\ Universitas Airlangga \\ Surabaya \\ diansabrina@ymail.com
}

\begin{abstract}
Abstrak
Pemilihan umum merupakan konsekuensi dari sebuah Negara demokrasi yang diatur dalam Pasal 1 ayat (2) Undang-Undang Dasar Negara Republik Indonesia Tahun 1945 (UUD NRI 1945). Prinsip negara demokrasi hendaklah dibangun dan dikembangkan menurut prinsip-prinsip demokrasi atau kedaulatan rakyat (democration rechtstaat), prinsip demokrasi melahirkan pemilu yang demokratis. Namun dalam pemilihan Presiden dan Wakil Presiden tidak dilakukan secara adil bagi partai politik peserta pemilu. Penelitian ini mengkaji sejauh mana presidential threshold memberikan keadilan bagi pelaksanaan pemilu khususnya terkait hak partai politik sebagai peserta pemilu. Tujuan yang hendak di capai adalah membangun system demokrasi yang berkeadilan. Penelitian ini menggunakan metode deskriptif analitis dengan pendekatan yuridis normatif, di mana data dan informasi dianalisis secara normatif. Hasil penelitian menunjukkan bahwa pentingnya persamaan hak dalam penentuan ambang batas dengan tidak menghilangkan hak minoritas partai politik peserta pemilu dalam pengusulan calon Presiden dan Wakil Presiden.
\end{abstract}

Kata Kunci : Keadilan, Pemilu, Presidential Theshold.

\begin{abstract}
General elections are a consequence of a democratic country regulated in Article 1 paragraph (2) of the 1945 Constitution of the Republic of Indonesia (UUD NRI 1945). The principle of a democratic state should be built and developed according to the principles of democracy or people's sovereignty (demonstration rechtstaat), the principles of democracy give birth to democratic elections. However, the election for the President and Vice President is not conducted fairly for the political parties participating in the election. This study examines the extent to which the presidential threshold provides justice for the implementation of elections, especially regarding the rights of political parties as election participants. This study uses a descriptive analytical method with a normative juridical approach, in which data and information are analyzed normatively. The results showed that the importance of equal rights in determining the threshold by not eliminating the minority rights of political parties participating in the elections in proposing candidates for President and Vice President.
\end{abstract}

Keywords: Justice, Election, Presidential Theshold.

\section{A. Pendahuluan}

Sebagai konsekuensi dari kerangka pemikiran bahwa konstitusi merupakan hasil perjanjian bersama seluruh rakyat, yang berdasarkan teori kedaulatan rakyat merupakan pemegang kekuasaan tertinggi, maka konstitusi menduduki tempat sebagai hukum tertinggi dalam kehidupan berbangsa dan bernegara (the supreme law of the land). Bahkan, konstitusi yang secara etimologis berasal dari kata "to constitute" yang berarti membentuk, juga dapat diartikan sebagai dokumen pembentuk organisasi negara. Oleh karena itu konstitusi mengikat segenap komponen negara, baik penyelenggara maupun warga negara ${ }^{1}$.

\footnotetext{
${ }^{1}$ Brian Thompson,1997, Texbook on Constitutional and Administrative Law, Ondon, Blackstone Press Ltd., h. 3
} 
Konstitusi merupakan dokumen penting yang mengandung peraturan-peraturan dasar mengenai struktur pemerintahan, hak dan kewajiban serta pembatasan kekuasaan dan kewenangan negara, konstitusi merupakan hukum dasar (grundnorm), maka secara lebih luas biasa berwujud teks tertulis (written texts) dan tidak tertulis (unwritten texts), hal tersebut tergantung pada sistem hukum yang dianut antara civil law atau common law ${ }^{2}$. Dalam sejarah ketatanegaraan Indonesia merdeka, telah mencatat beberapa upaya yaitu pembentukan undang-undang dasar, pergantian undang-undang dasar, perubahan dalam arti pembaruan undang-undang dasar ${ }^{3}$.

Berdasarkan wewenang Mahkamah Konstitusi sebagaimana diatur dalam UndangUndang Dasar Negara Republik Indonesia Tahun 1945 Mahkamah Konstitusi mengemban fungsi sebagai pengawal konstitusi (the guardian of the constitution). Hal tersebut membawa konsekuensi Mahkamah Konstitusi sebagai penafsir konstitusi (the sole interpreter of the constitution). Konstitusi sebagai hukum tertinggi mengatur penyelenggaraan negara berdasarkan prinsip demokrasi dan salah satu fungsi konstitusi adalah melindungi HAM. Oleh karena itu Mahkamah Konstitusi juga berfungsi sebagai pengawal demokrasi (the guardian of the democracy), pelindung hak konstitusional warga negara (the protector of the citizen's constitutional rights) dan pelindung HAM (the protector of human rights). Dalam konteks ketiga fungsi tersebut.

David Held ${ }^{4}$ memberikan konsepsi hubungan antara demokrasi, negara dan kebutuhan konstitusionalnya di mana ketiganya menjadi satu kesatuan sistemik dalam rangka memperkuat hak dan kewajiban dalam hukum publik yang demokratis. Hal itu menunjukkan bahwa pembentukan Mahkamah Konstitusi merupakan implementasi dari gagasan negara hukum yang salah satu cirinya adalah menempatkan konstitusi sebagai hukum tertinggi. Kewenangan yang dimiliki Mahkamah Konstitusi merupakan sarana untuk menjadikan konstitusi sebagai dokumen hidup (a living document) yang menentukan bentuk dan arah kekuasaan negara sesuai dengan prinsip dasar dalam konstitusi berdasarkan demokrasi ${ }^{5}$.

\footnotetext{
2 Jawahir Thontowi, 2002, Islam Politik dan Hukum: Esai-esai Ilmiah untuk, pembaharuan, Cetakan I, Yogyakarta, Madyan Press, h. 150.

${ }^{3}$ Taufiqurrahman Syahuri, 2011, Tafsir Konstitusi Berbagai Aspek Hukum, Jakarta, Kencana Prenada Media Group, h. 22.

${ }^{4}$ David Held, 1995, Democracy and the Global Order: From the Modern State to Cosmopolitan Governance, Stanford, Stanford University Press, h. 157.

${ }^{5}$ I Dewa Gede Palguna, 2011, Pengaduan Konstitusional: Upaya Hukum Terhadap Pelanggaran Hak-Hak Konstitusional Warga Negara (Studi Kewenangan Mahkamah Konstitusi Indonesia dalam Perspektif Perbandingan), Disertasi, Jakarta, Program Doktor Ilmu Hukum Universitas Indonesia, h. 157.
} 
Mahkamah Konstitusi memberi kontribusi bagi terciptanya kehidupan bernegara berdasarkan hukum dan demokrasi.

Pemilihan umum merupakan konsekuensi dari sebuah Negara demokrasi yang diatur dalam Pasal 1 ayat (2) Undang-Undang Dasar Negara Republik Indonesia Tahun 1945 (UUD NRI 1945). Prinsip negara demokrasi hendaklah dibangun dan dikembangkan menurut prinsip-prinsip demokrasi atau kedaulatan rakyat (democration rechtstaat) ${ }^{6}$. Hal ini telah diatur dalam Undang-Undang Dasar Negara Republik Indonesia Tahun 1945 Pasal 22E Tentang Pemilihan Umum.

Pemilihan Umum Presiden dan Wakil Presiden merupakan bagian dari skema Pemilihan Dewan Perwakilan Rakyat (DPR), Dewan Perwakilan Daerah (DPD), dan Dewan Perwakilan Daerah (DPRD) yang terdapat dalam pasal $22 \mathrm{E}$ ayat (2) Undang-Undang Dasar Negara Republik Indonesia Tahun 1945. Pemilihan umum (Pemilu) merupakan instrument penting dalam negara demokrasi yang menganut sistem perwakilan, pemilu berfungsi sebagai alat penyaring bagi "politikus-politikus" yang akan mewakili dan membawa suara rakyat di dalam lembaga perwakilan dan mereka yang terpilih dianggap sebagai orang atau kelompok yang mempunyai kemampuan atau kewajiban untuk bicara dan bertindak atas nama suatu kelompok yang lebih besar melalui partai politik ${ }^{7}$.

Mengenai pelaksanan waktu pengusulan Calon Presiden dan Wakil Presiden dalam Pasal 9 Undang-Undang Nomor 42 Tahun 2008 tentang Pemilihan Umum. Undang-Undang Pemilihan Presiden apabila dikaitkan dengan Pasal 6A ayat (2) Undang-Undang Dasar Negara Republik Indonesia Tahun 1945, hal ini menimbulkan pertanyaan yaitu apakah waktu pengusulan pemilu Presiden dan wakil Presiden sebagaimana dalam Pasal 9 Undang-Undang Pemilihan Presiden sesuai dengan pengaturan waktu pengusulan calon Presiden dan Wakil Presiden yang dimaksudkan oleh Pasal 6A Ayat (2) Undang-Undang Dasar Negara Nepublik Indonesia Tahun 1945, yakni sebelum pelaksanaan pemilihan umum. Pengaturan Pasal 9 Undang-Undang Pemilihan Presiden tersebut haruslah sesuai dengan konstitusi Republik Indonesia yang menjamin hak-hak warga negara berupa persamaan kedudukan di dalam hukum dan pemerintahan yang diakui secara normatif dan dilaksanakan secara empirik ${ }^{8}$. Sebagaimana yang telah digariskan dalam Pasal 27 ayat (1), selain itu pula konstitusi Republik Indonesia menjamin adanya hak untuk memperoleh pengakuan, jaminan, perlindungan, dan

\footnotetext{
${ }^{6}$ Ni'matul Huda, 2014, Perkembangan Hukum Tata Negara, Yogyakarta, FH.UII Press, h. 346.

${ }^{7}$ Mahfud MD, 2017, Politik. Hukum di Indonesia, Jakarta, Rajawali Pers, h. 60.

8 Jimly Assidiqie, 2011, Konstitusi dan Konstitusionalisme Indonesia, Jakarta, Sinar Grafika, h. 128.
} 
kepastian hukum yang adil serta perlakuan yang sama dihadapan hukum Pasal 28D ayat (1), dan hak untuk memperoleh kesempatan yang sama dalam pemerintahan Pasal $28 \mathrm{D}$ ayat (3), serta hak untuk bebas dari segala bentuk diskriminasi Pasal 28I ayat (2) Semuanya itu merupakan perwujudan kedaulatan rakyat yang telah digariskan dalam Pasal 1 ayat (2).

Partai politik merupakan salah satu bentuk perwujudan kebebasan berserikat sebagai salah-satu prasyarat berjalannya demokrasi. Kebebasan berserikat lahir dari kecenderungan dasar manusia untuk hidup bermasyarakat dan berorganisasi baik secara formal maupun informal, kecendrungan demikian itu merupakan suatu keniscayaan (organizational imperatives) kecenderungan bermasyarakat yang pada prinsipnya menurut pandangan Locke dan Rousseau adalah kehidupan berorganisasi timbul untuk memenuhi kebutuhan dan kepentingan-kepentingan yang sama dari individu-individu serta untuk mencapai tujuan bersama berdasarkan persamaan pikiran dan hati nurani, oleh karena itu dalam perkembangannya kebebasan berserikat menjadi salah satu kebebasan dasar manusia yang diakui secara universal sebagai bagian dari hak asasi manusia dengan istilah kemerdekaan berserikat (freedom of association $)^{9}$.

Perkembangan sistem demokrasi tidak langsung yang tetap dapat menjamin kepentingan dan kehendak warga negara, tetap menjadi penentu. Demokrasi melalui partisipasi langsung bergeser menjadi demokrasi perwakilan, rakyat tetap memegang kekuasaan tertinggi namun pelaksanaanya dilakukan oleh wakil-wakil yang dipilih rakyat . Demokrasi dalam arti harfiah adalah pemerintahan oleh rakyat, hal itu berarti rakyatlah yang benar-benar memerintah yaitu mengambil keputusan bersama dalam suatu majelis yang diikuti oleh seluruh rakyat. Menurut MacIver praktik demokrasi hanya mungkin dijalankan pada negara yang wilayah dan jumlah warganya sangat kecil. Dalam perkembangannya, demokrasi yang melibatkan rakyat secara langsung dalam pemerintahan tidak mungkin dilaksanakan.

Secara teori yang termasuk dalam infrastruktur politik adalah partai politik (political parties) ${ }^{10} \quad$ Pemerintahan modern yang demokratis adalah pemerintahan yang dibentuk melalui pemilihan umum yang diikuti oleh partai politik. Partai politik memainkan peran dalam pemilihan organ legislatif ataupun eksekutif, dengan menentukan calon-calon yang akan dipilih. Mekanisme penentuan calon tersebut biasanya menjadi masalah internal partai

\footnotetext{
${ }^{9}$ Muhamad Ali Safa'at, 2011, Pembubaran Partai Politik, Jakarta, Rajawali Pers, h. 14.

${ }^{10}$ Sri Soemantri M, 2014, Hukum Tata Negara Indonesia pemikiran dan Pandangan, Bandung, Remaja Rosdakarya, h. 128
} 
politik inilah yang disebut fungsi rekrutmen politik dan dapat dikatakan bahwa pemerintahan demokrasi modern dibentuk dari satu partai atau koalisi beberapa partai. Hal ini sesuai dengan amanat dalam konstitusi yang tertuang dalam pasal 6A ayat (2) yang menyatakan bahwa pasangan calon Presiden dan Wakil Presiden diusulkan oleh partai politik atau gabungan partai politik peserta pemilihan umum sebelum pelaksanaan pemilihan umum.

Berdasarkan Peraturan Komisi Pemilihan Umum Nomor 5 Tahun 2018 Tentang perubahan atas Peraturan Komisi Pemilihan Umum Nomor 7 Tahun 2017 Tentang Tahapan, Program dan Jadwal Penyelenggaraan Pemilu 2019 dan berdasarkan Surat Keputusan Komisi Pemilihan Umum tentang Penetapan Partai Politik Sebagai Peserta Pemilu 2019 yang dinyatakan lolos verifikasi secara keseluruhan adalah 19 partai politik yang terdiri dari 11 partai lama peserta pemilu dan 4 partai baru yakni PSI, Perindo, Berkarya, dan Partai Garuda serta Partai Lokal diantaranya adalah Partai Daerah Aceh, Partai Sira, dan Partai Nangroe Aceh yang tidak terdaftar sebagai partai politik peserta pemilu pada pemilihan umum sebelumnya. sistem Pemerintahan Presidensial, kekuasaan eksekutif dipegang oleh Presiden dan dibantu oleh satu orang Wakil Presiden dengan kewenangan penyelenggaraan pemerintahan. Dalam hal pencalonan pasangan calon Presiden dikenal konsep presidential threshold sebagai syarat hukum pengajuan pasangan calon Presiden dan Wakil Presiden untuk dipilih dalam pemilihan umum.

Calon Presiden dan Wakil Presiden diusung oleh partai atau gabungan partai peserta pemilu 2019, dimana partai tersebut dinyatakan lolos verifikasi oleh Komisi Pemilihan Umum, berdasarkan Peraturan Komisi Pemilihan Umum Nomor 11 Tahun 2017 Tentang syarat-syarat pendaftaran dan verifikasi partai politik peserta pemilu 2019. Peraturan Komisi Pemilihan Umum Nomor 11 Tahun 2017 pasal 10 ayat (1) adalah setiap partai politik peserta pemilu 2019 wajib memenuhi setidaknya 10 syarat yang sudah diatur, yaitu berstatus badan hukum sesuai dengan undang-undang partai politik, memiliki kepengurusan paling sedikit 75\% dari jumlah kabupaten/kota di provinsi yang bersangkutan, memiliki kepengurusan paling sedikit di 50\% jumlah kecamatan, menyertakan paling sedikit, 30\% keterwakilan perempuan pada kepengurusan partai politik tingkat pusat, memiliki anggota paling sedikit 1.000 atau 1/1.000 dari jumlah penduduk, memiliki kantor tetap untuk kepengurusan pada tingkat pusat provinsi hingga kota, mengajukan nama, lambang, dan tanda partai politik Komisi Pemilihan Umum, menyerahkan nomor rekening atas nama partai, dan menyerahkan AD/ART partai politik dan syarat ini dibuat sebagai pembatasan kekuasan partai pemilu dalam penyelenggaraan pemilihan umum. 
Pembatasan kekuasaan negara diperlukan sebagai wujud paham konstitusionalisme, yaitu paham bahwa kekuasaan harus dibatasi agar negara dapat dijalankan sesuai dengan pembentukan negara itu sendiri. Dari sudut pandang ini, konstitusi berfungsi sebagai pembatas kekuasaan. Oleh karena itu tanpa adanya pembatasan kekuasaan, suatu konstitusi kehilangan ruh konstitusionalisme dan hanya akan menjadi legitimasi bagi kekuasaan negara yang tak terbatas. Hal ini dikemukakan oleh Erict Barent bahwa "constitusionalism is a belief in composition of restrains on governance by mean a constitution ${ }^{11}$ " konstitusi sebagai pembatas kekuasaan juga dapat dipahami dari tiga pengertian pokok yang disampaikan oleh C.J Bax dan G.F.M van der Tang, yaitu:

1. A state, or any system of government, must be founded upon law, while the power exercised within the state should conform to definite legal rules and procedures.

2. The institutional structure of government should ensure the power resides with, or is divided among, different branches which mutually control their exercise of power and which are obliged to co-operate.

3. The relationship between the government and the individual members of society should be regulated in such manner that leaves the latter's basic right and freedom unimpaired ${ }^{12}$.

Salah satu bentuk pembatasan kekuasaan dalam konstitusi adanya jaminan perlindungan Hak Asasi Manusia (HAM). Jaminan perlindungan HAM di dalam konstitusi sebagai hukum tertinggi bermakna bahwa negara pun dilarang melakukan pelanggaran HAM dan bahkan tugas utama perlindungan HAM adalah pada negara. Kegiatan pemilu merupakan sarana penyaluran hak asasi warga negara yang prinsipil. Oleh karena itu, dalam rangka pelaksanaan hak asasi warga negara menjadi suatu keharusan bagi pemerintah untuk mejamin terselenggaranya pemilu sesuai dengan jadwal ketatanegaraan yang ditentukan. Jimly Asshiddiqie ${ }^{13}$ menyatakan bahwa ketentuan HAM di dalam UUD 1945 setelah perubahan terdapat di dalam 37 butir ketentuan yang diklasifikasi ke dalam empat kelompok, yaitu pertama, kelompok ketentuan yang menyangkut hak-hak sipil yang meliputi:

1. Setiap orang berhak untuk hidup, mempertahankan hidup dan kehidupannya;

2. Setiap orang berhak untuk bebas dari penyiksaan, perlakuan, atau penghukuman lain yang kejam, tidak manusiawi dan merendahkan martabat kemanusiaan;

3. Setiap orang berhak untuk bebas dari segala bentuk perbudakan;

4. Setiap orang bebas memeluk agama dan beribadat menurut agamanya;

5. Setiap orang berhak untuk bebas memiliki keyakinan, pikiran, dan hati nurani;

6. Setiap orang berhak untuk diakui sebagai pribadi dihadapan hukum;

7. Setiap orang berhak atas perlakuan yang sama di hadapan hukum dan pemerintahan;

\footnotetext{
${ }^{11}$ Eric Barent,1998, An Introduction to Constitutional Law, Oxford: Oxford University Press, h. 14.

${ }^{12}$ Carla M. Zoethout et all. (eds.), 1993, Controlin Constitusional Law, Nederland, Martinus Nijhoff Publisher, h. 88.

${ }^{13}$ Jimly Assiddiqie-I, 2010, Pengantar Imu Hukum Tata Negara, Jakarta, Raja Grafindo utama, h. 416.
} 
8. Setiap orang berhak untuk tidak dituntut atas dasar hukum yang berlaku surut;

9. Setiap orang berhak untuk membentuk keluarga dan melanjutkan keturunan melalui perkawinan yang sah;

10. Setiap orang berhak atas status kewarganegaraan;

11. Setiap orang berhak untuk bertempat tinggal di wilayah negaranya, meninggalkan, dan kembali ke negaranya;

12. Setiap orang berhak memperoleh suaka politik;

13. Setiap orang berhak bebas dari segala bentuk perlakuan diskriminatif dan berhak mendapatkan perlindungan hukum dari perlakuan yang bersifat diskriminatif tersebut.

Kelompok kedua adalah hak politik, ekonomi, sosial, dan budaya yang meliputi

1. Setiap warga negara berhak untuk berserikat, berkumpul, dan menyatakan pendapatnya secara damai dengan lisan dan tulisan;

2. Setiap warga negara berhak untuk memilih dan dipilih dalam rangka lembaga perwakilan rakyat;

3. Setiap warga negara dapat diangkat untuk menduduki jabatan-jabatan publik;

4. Setiap orang berhak untuk memperoleh dan memilih pekerjaan yang sah dan layak bagi kemanusiaan;

5. Setiap orang berhak untuk bekerja, mendapat imbalan, dan mendapat perlakuan yang layak dalam hubungan kerja yang berkeadilan;

6. Setiap orang berhak mempunyai hak milik pribadi;

7. Setiap warga negara berhak atas jaminan sosial yang dibutuhkan untuk hidup layak dan memungkinkan pengembangan dirinya sebagai manusia yang bermartabat

8. Setiap orang berhak untuk berkomunikasi dan memperoleh informasi;

9. Setiap orang berhak untuk memperoleh dan memilih pendidikan dan pengajaran;

10. Setiap orang berhak mengembangkan dan memperoleh manfaat dari ilmu pengetahuan dan teknologi, seni dan budaya untuk meningkatkan kualitas hidup dan kesejahteraan umat manusia;

11. Negara menjamin penghormatan atas identitas budaya dan hak-hak masyarakat lokal selaras dengan perkembangan zaman dan tingkat peradaban bangsa-bangsa;

12. Negara mengakui setiap budaya sebagai bagian dari kebudayaan nasional;

13. Negara menjamin kemerdekaan tiap-tiap penduduk untuk memeluk agamanya masing-masing, dan untuk beribadah menurut kepercayaannya itu.

Ketiga, kelompok hak-hak khusus dan hak atas pembangunan yang meliputi:

1. Setiap warga negara yang menyandang masalah sosial, termasuk kelompok masyarakat yang terasing dan yang hidup di lingkungan terpencil, berhak mendapatkan kemudahan dan perlakuan khusus untuk memperoleh kesempatan yang sama;

2. Hak perempuan dijamin dan dilindungi untuk mencapai kesetaraan gender dalam kehidupan nasional;

3. Hak khusus yang melekat pada diri perempuan yang dikarenakan oleh fungsi reproduksinya dijamin dan dilindungi oleh hukum;

4. Setiap anak berhak atas kasih sayang, perhatian, dan perlindungan orangtua, keluarga, masyarakat dan negara bagi pertumbuhan fisik dan mental serta perkembangan pribadinya;

5. Setiap warga negara berhak untuk berperan serta dalam pengelolaan dan turut menikmati manfaat yang diperoleh dari pengelolaan kekayaan alam;

6. Setiap orang berhak atas lingkungan hidup yang bersih dan sehat; 
7. Kebijakan, perlakuan atas tindakan khusus yang bersifat sementara dan dituangkan dalam peraturan perundang-undangan yang sah yang dimaksudkan untuk menyetarakan tingkat perkembangan kelompok tertentu yang pernah mengalami perlakuan diskriminatif dengan kelompok-kelompok lain dalam masyarakat, dan perlakuan khusus tersebut tidak termasuk dalam pengertian diskriminatif.

Keempat, kelompok yang mengatur mengenai tanggung jawab negara dan kewajiban hak asasi manusia yang meliputi:

1. Setiap orang wajib menghormati hak asasi manusia orang lain dalam tertib kehidupan bermasyarakat, berbangsa, dan bernegara;

2. Dalam menjalankan hak dan kebebasannya, setiap orang wajib tunduk pada pembatasan yang ditetapkan oleh undang-undang dengan maksud semata-mata untuk menjamin pengakuan dan penghormatan atas hak dan kebebasan orang lain serta untuk memenuhi tuntutan keadilan sesuai dengan nilai-nilai agama, moralitas, dan kesusilaan, keamanan, dan ketertiban umum dalam masyarakat yang demokratis;

3. Negara bertanggung jawab atas perlindungan, pemajuan, penegakan, dan pemenuhan hak-hak asasi manusia;

4. Untuk menjamin pelaksanaan hak asasi manusia, dibentuk Komisi Nasional Hak Asasi Manusia yang bersifat independen dan tidak memihak yang pembentukan, susunan, dan kedudukannya diatur dengan undang-undang.

Di dalam UUD NRI Tahun 1945 terdapat hak yang dikategorikan sebagai hak yang tidak dapat dikurangi dalam keadaan apapun atau non-derogable rights di dalam pasal 28I ayat (1), yaitu:

1. Hak untuk hidup;

2. Hak untuk tidak disiksa;

3. Hak kemerdekaan pikiran dan hati nurani;

4. Hak beragama;

5. Hak untuk tidak diperbudak;

6. Hak untuk diakui sebagai pribadi dihadapan hukum; dan

7. Hak untuk tidak dituntut atas dasar hukum yang berlaku surut.

Penyelenggaraan pemilu sangat terkait dengan HAM. Pemilu sebagai mekanisme demokrasi modern adalah wujud dari prinsip kedaulatan rakyat yang menempatkan manusia dalam derajat yang sama. Kesederajatan tersebut mengharuskan pembentukan kekuasaan yang memonopoli dan bersifat memaksa hanya dapat dilakukan oleh atau setidak-tidaknya dengan persetujuan manusia yang diperintah. Pemilu adalah upaya untuk mewujudkan pemerintahan dari, oleh, dan untuk rakyat. Oleh karena itu, penyelenggaraan pemilu adalah wujud nyata pengakuan HAM dalam kehidupan bernegara.

Undang-Undang Nomor 7 Tahun 2017 Tentang Pemilihan Umum pasal 222 menyatakan bahwa ketentuan yang masih mengatur adanya ambang batas pencalonan Presiden sebesar 20\% jumlah kursi Dewan Perwakilan Rakyat (DPR) atau 25\% dari total suara sah hasil pemilu 2014 dianggap tidak sejalan dengan Undang-Undang Dasar Negara Republik Indonesia Tahun 1945 karena dalam pasal 222 Undang-Undang Nomor 7 Tahun 2017 Tentang Pemilu tidak memberikan kebebasan kepada masyarakat dalam menentukan 
pilihan. Hal ini dianggap bertentangan dengan pasal 6A ayat (2), pasal 22E ayat (1), pasal 27 ayat (1), pasal 28D ayat (1), dan pasal 28D ayat (3) Undang-Undang Dasar Negara Republik Indonesia Tahun 1945. Undang-Undang Nomor 7 Tahun 2017 tentang Pemilu menegaskan, bahwa calon Presiden dan Wakil Presiden diusulkan dalam 1 (satu) pasangan oleh partai politik atau gabungan partai politik, yang memenuhi persyaratan perolehan kursi paling sedikit 20\% (dua puluh persen) dari suara sah secara nasional pada pemilu anggota DPR sebelumnya. Partai politik atau gabungan partai politik sebagaimana dimaksud pasal 223 ayat (2) Undang-Undang Nomor 7 Tahun 2017 tentang pemilu hanya dapat mencalonkan 1 (satu) pasangan calon sesuai dengan mekanisme internal partai politik yang dilakukan secara demokratis dan terbuka.

Perselisihan terkait ambang batas tersebut mengakibatkan Mahkamah Konstitusi harus bekerja keras dalam putusannya karena mengingat bahwa pemilihan Presiden dan Wakil Presiden akan diselenggarakan pada tahun 2019. Berdasarkan Putusan Mahkamah Konstitusi sebelumnya nomor 14/PUU-XI/2013 mengabulkan sebagian dari permohonan pemohon untuk membatalkan Pasal 3 ayat 5 tentang pelaksanaan pemilu presiden pasca pemilu legislatif, Pasal 12 Ayat 1 dan 2 tentang kebolehan partai politik mengumumkan siapa pasangan calon presidennya pada kampanye pemilu legislatif, Pasal 14 Ayat 2 tentang masa pendaftaran calon presiden pasca penetapan hasil pemilu legislatif dan Pasal 112 tentang pelaksanaan pemilu presiden dan wakil presiden pasca penetapan hasil pemilu legislatif.

Putusan Mahkamah Konstitusi tersebut, dapat dilihat bahwa penyelenggaraan pemilihan Presiden dan Wakil Presiden tidak lagi dilaksanakan pasca pemilihan umum legislatif, hal ini sebenarnya telah diatur dalam Pasal 6A ayat 2 UUD 1945 yang berbunyi "Pasangan calon Presiden dan Wakil Presiden diusulkan oleh partai politik atau gabungan partai politik peserta pemilihan umum sebelum pelaksanaan pemilihan umum" prasa pemilihan umum kedua dalam pasal tersebut merujuk pada Pasal 22E ayat 2 UUD 1945 yang berbunyi "Pemilihan umum diselenggarakan untuk memilih anggota Dewan Perwakilan Rakyat, Dewan Perwakilan Daerah, Presiden dan wakil presiden dan Dewan Perwakilan Rakyat Daerah". Jadi putusan Mahkamah Konstitusi bertujuan memperjelas inkonsistensi penerapan Pasal 6A ayat 2 dan Pasal 22E ayat 2 UUD 1945. Ketentuan Pasal 9 UndangUndang Nomor 42 Tahun 2008 yang mengatur ambang batas pemilu presiden (presidential threshold) tidak dikabulkan oleh Mahkamah Konstitusi, sehingga pemilu Tahun 2019 dilaksanakan secara serentak namun harus pula menggunakan presidential treshold sebagai acuan pencalonan. Terkait hal ini, keberadaan presidential threshold tidak akan mengganggu 
jalannya pemilihan umum serentak 2019, karena penggunaan presidential threshold dapat dilakukan dengan menggunakan hasil suara sah ataupun kursi pada pemilihan legislatif 2014 sebagai dasar penggunakan presidential threshold.

Presidential threshold merupakan suatu konsep yang bertujuan untuk mengusulkan calon Presiden dan Wakil Presiden berkualitas. Pengusulan ini dilakukan oleh partai politik atau gabungan partai politik yang bertanggungjawab terhadap pasangan calon Presiden dan Wakil Presiden yang diusung. Kendati demikian, beberapa pihak berpendapat bahwa presidential trheshold tidak tepat dilaksanakan mengingat hanya partai yang memiliki suara atau kursi besar saja yang dapat mencalonkan presiden dan wakil presiden, sementara partai dengan suara dan kursi kecil tidak dapat mengusulkan calon Presiden dan Wakil Presiden.

Ketentuan tata cara penentuan pasangan calon Presiden dan Wakil Presiden pada Pemilu 2019, diatur dalam Pasal 222 Undang-Undang Nomor 7 Tahun 2017 tentang Pemilihan umum. Pasal 222 menyatakan bahwa "Pasangan Calon diusulkan oleh Partai Politik atau Gabungan Partai Politik Peserta Pemilu yang memenuhi persyaratan perolehan kursi paling sedikit 20\% (dua puluh persen) dari jumlah kursi DPR atau memperoleh 25\% (dua puluh lima persen) dari suara sah secara nasional pada Pemilu anggota DPR sebelumnya"

Pengaturan ambang batas sebagaimana diatur dalam Undang-Undang Nomor 7 Tahun 2017 tentang Pemilihan Umum merupakan penjabaran dari UUD NRI Tahun 1945 Pasal 6A ayat (2). UUD NRI 1945 Pasal 6A ayat (2) menyatakan bahwa "Pasangan calon Presiden dan Wakil Presiden diusulkan oleh partai politik atau gabungan partai politik peserta pemilihan umum sebelum pelaksanaan pemilihan umum”. Ketentuan yang terdapat dalam UUD NRI Tahun 1945 Pasal 6A ayat (2) mempunyai perbedaan dengan Pasal 222 UndangUndang Nomor 7 Tahun 2017 tentang Pemilihan Umum. UUD NRI Tahun 1945 Pasal 6A ayat (2) tidak menentukan berapa jumlah suara sebagai syarat pencalonan Presiden dan Wakil Presiden sedangkan Pasal 222 Undang-Undang Nomor 7 Tahun 2017 tentang Pemilihan Umum, menentukan secara eksplisit jumlah suara sebagai syarat pencalonan Presiden dan Wakil Presiden.

Penerapan ambang batas sesungguhnya tidak hanya terjadi untuk Pemilu 2019 saja namun sudah ada jauh sebelum pelaksanaan Pemilu 2019. Jika melihat sejarah, maka penerapan ambang batas sudah ada sejak dilaksanakannya Pemilihan Presiden dan Wakil Presiden secara langsung oleh rakyat yang dimulai pada tahun 2004. Pemilu, sebelum Pemilu 2019, dilaksanakan dengan dua instrumen hukum yaitu instrumen hukum untuk pemilihan 
anggota DPR, DPD, dan DPRD serta instrumen hukum untuk pemilhan Presiden dan Wakil Presiden. Pemilu yang dilaksanakan melalui dua instrumen hukum hanya berlaku sampai dengan Pemilu anggota DPR, DPD, dan DPRD serta Pemilu Presiden dan Wakil Presiden 2014.

Pemilu 2019 diatur dengan satu instrumen hukum yaitu Undang-Undang Nomor 7 Tahun 2017 karena Pemilu 2019 dilaksanakan secara serentak. Pemilu yang dimaksud dilaksanakan secara serentak yaitu Pemilu DPR, DPD, DPRD, serta Presiden dan Wakil Presiden dilaksanakan secara bersama-sama dalam satu waktu. Sejarah pengaturan ambang batas Pemilu 2004 sampai dengan Pemilu 2019 dalam kenyataannya tidak ditentukan dengan persentase dan jumlah perolehan suara sah secara nasional yang sama dalam menentukan ambang batas. Persentase ambang batas dan jumlah perolehan suara sah secara nasional pemilihan Presiden dan Wakil Presiden secara langsung tahun 2004 sampai dengan 2019 mengalami perubahan. Kecendrungan partai politik untuk memenuhi ambang batas yang telah diatur dalam undang-undang pemilu lebih memilih berkoalisi dengan partai politik yang memiliki ambang batas lebih besar agar partai politik tersebut memiliki hak suara dalam pengusulan calon Presiden dan Wakil Presiden. hal ini pula yang mengakibatkan menumpuknya partai politik yang berkoalisi sehingga calon yang dilahirkan dari ambang batas tersebut menjadi terbatas.

Pengalaman 2 kali masa pemilihan Presiden dan Wakil Presiden hanya melahirkan 2 calon Presiden dan Wakil Presiden pada periode masa pemilu tahun 2014-2019 dan masa 2019-2024. Hal tersebut membuat masyarakat dipaksakan untuk memilih calon yang telah disediakan meskipun calon tersebut belum tentu calon yang diharapkan masyarakat sehingga tidak ada alternatif lain dalam proses pemilihan Presiden dan Wakil Presiden.

Ketentuan partai politik peserta pemilu pada Pemilu 2019 juga telah diatur dalam Undang-Undang Nomor 7 Tahun 2017 tentang Pemilihan Umum dalam Bab XI Pasal 414 dan 415. Pasal 414 ayat (1) menyatakan bahwa "Partai Politik Peserta Pemilu harus memenuhi ambang batas perolehan suara paling sedikit 4\% (empat persen) dari jumlah suara sah secara nasional untuk diikutkan dalam penentuan perolehan kursi anggota DPR”. Selanjutnya Pasal 415 ayat (1) menyatakan bahwa "Partai Politik Peserta Pemilu yang tidak memenuhi ambang batas perolehan suara sebagaimana dimaksud dalam Pasal 414 ayat (1) tidak disertakan pada penghitungan perolehan kursi DPR di setiap daerah pemilihan". Ketentuan Pasal 414 dan Pasal 415 tersebut berdampak pada parpol yang semakin kecil peluangnya dalam pengusungan calon Presiden dan Wakil Presiden, dan berdampak pula kepada parpol dalam 
mencalonkan Presiden dan Wakil Presiden yang berasal dari kandidatnya sendiri, hal ini juga berakibat pada calon Presiden dan Wakil Presiden yang hanya terdiri dari 2 (dua) pasang calon, atau hanya 1 (satu) pasang calon (calon tunggal) dan menimbukan suara rakyat tidak tersalurkan melalui parpol.

Franz Magnis Suseno dalam bukunya Etika Politik (Prinsip-prinsip Moral Dasar Kenegaraan Modern) bahwa kriteria hukum yang ditetapkan secara objektif dan yang samasama berlaku bagi semua, baik bagi yang lemah, maupun bagi yang kuat. Dalam fungsi hukum ini nampak dua nilai yang secara hakiki mau dilindungi dan dijamin olehnya. Dua nilai itu adalah kesamaan dan kebebasan. Hanya karena dua nilai itu dihargai tinggi oleh manusia, kesewenangan kehidupan anggota masyarakat lain-lain perlu dicegah. Eksistensi hukum hanya masuk akal apabila hukum menjamin kesamaan. Kesamaan terutama dalam arti kesamaan kedudukan di hadapan hukum. Inti kesamaan yaitu bahwa kita diperlakukan menurut kriteria objektif yang berlaku bagi semua, dan bukan menurut siapa yang lebih mampu untuk memaksakan kehendaknya, dijamin oleh hukum juga dalam tatanan sosial yang foeda $1^{14}$.

Yang menjadi urgensi adalah terkait dengan adanya jaminan HAM terhadap warga Negara oleh konstitusi dalam pemilu adalah partai politik memiliki hak yang sama dalam pemilu, Hal ini menjadi persoalan hukum ketika pemilu yang akan diselengarakan oleh Komisi Pemilihan Umum dalam pemilihan Presiden dan Wakil Presiden khususnya pada tahap pengusulan calon Presiden dan Wakil Presiden yang melibatkan partai politik peserta pemilu tidak seluruh partai politik peserta pemilu dapat mengusung calon Presiden dan Wakil Presiden dengan dasar bahwa partai tersebut tidak ikut dalam pemilu dari periode sebelumnya dan tidak memiliki suara pada kursi legislatif pada pemilu sebelumnya berdasarkan sistem Presidential threshold.

\section{B. Telaah Konsep}

Keadilan adalah kebijakan utama dalam institusi sosial, sebagaimana kebenaran dalam sistem pemikiran. Suatu teori betapapun elegan dan ekonomisnya, harus ditolak atau direvisi jika ia tidak benar; demikian juga hukum dan institusi, tidak peduli betapapun efisien dan rapinya, harus direformasi atau dihapuskan jika tidak adil. Setiap orang memiliki kehormatan yang mendasar pada keadilan sehingga seluruh masyarakat sekalipun tidak bisa

\footnotetext{
${ }^{14}$ Franz Magnis Suseno,1991, Etike Politik, Jakarta, Gramedia, h. 114.
} 
membatalkannya. Atas dasar ini keadilan menolak jika lenyapnya kebebasan bagi sejumlah orang dapat dibenarkan oleh hal lebih besar yang didapatkan orang lain. Keadilan tidak membiarkan pengorbanan yang dipaksakan pada segelintir orang diperberat oleh sebagian besar keuntungan yang dinikmati banyak orang. Karena itu, dalam masyarakat yang adil kebebasan masyarakatnya dianggap mapan; hak-hak yang dijamin oleh keadilan tidak tunduk pada tawar-menawar politik atau kalkulasi kepentingan sosial. Mereka yang meyakini konsep keadilan yang berbeda bisa tetap sepakat bahwa institusi-institusi adalah adil ketika tidak ada perbedaan sewenang-wenang antar orang dalam memberikan hak dan kewajiban dan ketika aturan menentukan keseimbangan yang pas antara klaim-klaim yang saling berseberangan demi kemanfaatan kehidupan sosial ${ }^{15}$

Di tengah tidak adanya ukuran tertentu tentang kesepakatan mengenai mana yang adil dan mana yang tidak, jelas lebih sulit bagi para individu untuk mengoordinasikan rencanarencana mereka secara efisien dalam rangka menjamin bahwa tatanan yang saling menguntungkan tetap dipertahankan. Secara umum kita tidak bisa melihat konsepsi keadilan dengan peran distributifnya semata, betapapun bergunanya peran tersebut dalam mengidentifikasi konsep keadilan dan harus mempertimbangkan kaitan yang lebih luas; sebab kendati keadilan punya prioritas tertentu, menjadi kebajikan utama dari institusi. Hal ini menjadi persoalan ketika kedudukan partai politik dalam pemilu tidak memiliki hak dan kewajiban yang sama antara satu dengan yang lain sehingga terjadi ketidakadilan dalam proses pemilu di Indonesia.

KC Wheare pernah berkata "Constitutions is used to describe the whole system of Government of a country, the collection of rule which establish and regulate or govern the government. ${ }^{16 "}$ Esensi konstitusionalisme terdiri atas dua hal yang pertama, konsepsi negara hukum yang menyatakan bahwa secara universal kewibawaan hukum haruslah mengatasi kekuasaan pemerintah yang karenanya hukum harus mampu mengontrol dan mengendalikan politik; kedua, konsepsi hak-hak sipil warga negara yang menggariskan adanya kebebasan warga negara di bawah jaminan konstitusi sekaligus dapat diperoleh oleh konstitusi ${ }^{17}$.

Keadilan merupakan prinsip sekaligus mandat yang mesti diwujudkan dalam penyelenggaraan setiap pemilu. Konsep "keadilan" dalam pengertian hukum sebagaimana dikemukakan Hans Kelsen adalah Keadilan dinilai dari aspek kecocokan tindakan dengan

\footnotetext{
${ }^{15}$ John Rawls, 2011, A Theory of Justice Teori Keadilan, Yogyakarta, Pustaka Pelajar, h. 3.

${ }_{16}$ KC Wheare, 1996, Modern Constitution, London, Oxford University Press, h. 184.

${ }^{17}$ Mahfud MD, 2003, Demokerasi dan Konstitusi di Indonesia, Jakarta, Rineka Cipta, h. 145.
} 
hukum positif terutama kecocokan dengan undang-undang. Pemilu dianggap adil jika pelaksanaannya sesuai dengan aturan yang ada. Dalam konteks itu, makna adil hanyalah kata lain dari "benar". Sebab, penerapan hukum akan dikatakan "tidak adil" jika sebuah norma umum diterapkan pada satu kasus tetapi tidak diterapkan pada kasus sejenis lainnya yang muncul $^{18}$

Ramlan Surbakti sekalipun tidak memberikan definisi keadilan pemilu secara tegas, namun ia mengemukakan tujuh kriteria yang mesti dipenuhi untuk mewujudkan pemilu yang adil dan berintegritas. Tujuh kriteria tersebut adalah: 1). kesetaraan antarwarga negara, baik dalam pemungutan dan penghitungan suara maupun dalam alokasi kursi DPR dan DPRD dan pembentukan daerah pemilihan; 2). kepastian hukum yang dirumuskan berdasarkan asas pemilu demokratis; 3). persaingan bebas dan adil antar kontestan pemilu; 4). partisipasi seluruh pemangku kepentingan dalam seluruh rangkaian penyelenggaraan tahap pemilu; 5). badan penyelenggara pemilu yang profesional, independen, dan imparsial; 6). integritas pemungutan, penghitungan, tabulasi, dan pelaporan suara pemilu; 7). penyelesaian sengketa pemilu yang adil dan tepat waktu ${ }^{19}$.

Tujuh kriteria yang dikemukakan Ramlan di atas tidak hanya mengukur pemilu dari aspek regulasi dan tersedianya mekanisme komplain, melainkan juga menyentuh aspek kesetaraan antarwarga negara dan persaingan yang bebas dan adil. Kesetaraan antarwarga negara dijelaskan sebagai kesetaraan baik dalam pengajuan calon Presiden dan Wakil Presiden. Sementara persaingan yang bebas dan adil diartikan sebagai suatu kontestasi di mana para kontestan berangkat dan bersaing dari titik tolak atau titik star yang sama dan setara. Hal tersebut merupakan salah satu aspek penting dalam keadilan pemilu agar terwujudnya kesetaraan antarwarga negara dan terlaksananya kontestasi yang bebas dan adil, salah satunya adalah pada tahap pengusungan calon Presiden dan Wakil Presiden berdasarkan ambang batas.

Syarat ambang batas dianggap mengurangi hak rakyat untuk memperoleh pemimpin yang diinginkan. Sebab partai-partai itu harus berkoalisi yang bisa dipastikan gabungan parpol tersebut akan menghasilkan dukungan 20 persen lebih, tidak bisa pas 20\%. Dalam praktiknya, sejak ambang batas 20\% tersebut diberlakukan tahun 2009, maksimal hanya ada 2 pasangan calon. Dengan adanya pembatasan tersebut akan membatasi munculnya tokoh alternatif

\footnotetext{
${ }^{18}$ Hans Kalsen,1992, Introduction to The Problems of Legal Theory, translated by Bonnie Litschewski Paulson and Stanley L. Paulson, Clarendon Press, Oxford, h. 16.

${ }^{19}$ Ramlan Surbakti, 2014, Pemilu Berintegritas dan Adil, Harian Kompas edisi 14 Februari, h. 6.
} 
dalam kontestasi pemilihan Presiden dan Wakil Presiden. Pilihan rakyat dibatasi sehingga rakyat jadi apatis. Undang-undang pemilu sejatinya harus memfasilitasi munculnya calon pemimpin alternatif supaya persaingan elektoral semakin meningkat. Termasuk meningkatkan partisipasi dan kualitas pemimpinnya.

Teori keadilan Justinian adalah kebajikan yang memberikan hasil, bahwa setiap orang mendapat apa yang merupakan bagiannya berbeda dengan pendapat Herbert Spencer keadilan adalah setiap orang bebas untuk menentukan apa yang akan dilakukannya asal ia tidak melanggar kebebasan orang lain. Sama halnya menurut Nelson tidak ada arti lain bagi keadilan kecuali persamaan pribadi ${ }^{20}$.

Berbeda dengan keadilan justinian, keadilan distributif merupakan keadilan yang diberikan kepada tiap-tiap orang jatah menurut jasa atau prestasi masing-masing. Keadilan ini tidak menuntut persamaan (kualitas dan kuantitas), dan lebih mengedepankan tujuan hukum dari segi pemanfaatan dalam pemilu. Pemilu serentak berdasarkan ambang batas bertujuan meminimalisir anggaran yang dikeluarkan dalam pemilu serta waktu yang digunakan dalam pemilihan Presiden dan Wakil Presiden. Pemilu tanpa ambang batas menggunakan Keadilan Kommulatif ${ }^{21}$ yaitu keadilan yang memberikan kepada tiap-tiap orang yang sama banyaknya (kualitas dan kuantitas) tanpa memperhitungkan jasa-jasa atau prestasi masing-masing.

Larry Diamond and Richard Gunther ${ }^{22}$ dalam bukunya yang berjudul Political Parties and Democracy menyatakan bahwa untuk mencapai suatu tujuan dan menemukan beberapa implikasi yang berbeda dalam tipe- tipe partai untuk karakter dan kualitas dalam demokrasi politik terutama perlu identifikasi di berbagai fungsi yang dilakukan oleh parpol. Hal tersebut dijelaskan dalam bukunya yaitu "involves two distinct phases of the electoral' Sebelum masuk dalam fungsi partai ada dua fase yang berbeda dalam proses pemilu yang pertama adalah candidate nomination dimana para peserta pemilu yang mewakili masing-masing pihak dalam pemilihan partai dalam ruangan khusus; dan electoral mobilization, dimana partai-partai memotivasi mereka untuk masing-masing pilihan dalam mendukung kandidat mereka dan, dalam beberapa kasus, memfasilitasi keaktifan partisipan dalam proses pemilihan umum. fungsi partai yang lain diantaranya adalah issue structuring, this societal representation, interest aggregation, forming and sustaining goverments, and social integration. Hal ini sangat berpengaruh dengan kualitas

\footnotetext{
${ }^{20}$ Andi Abu Ayyub, 1987, Law in book and law in action,Jakarta Selatan, Yarsif Watampone, h. 60.

${ }^{21}$ Ibid,.

${ }^{22}$ Larry and Richard, 2001, Gunther, Political Parties and Democracy, USA, The Johns Hopkins University Press, h. 7 .
} 
partai dalam pemilu oleh karena itu parpol peserta pemilu dalam sistem demokrasi harus memiliki kedudukan yang sama mengingat partai berasal dari warga negara untuk berpartisipasi secara efektif dalam proses politik dan jika berhasil dalam tugas itu maka mereka akan merasa mempunyai sebuah pemberian penting dalam sebuah pengabdian di negara.

Pengertian demokrasi secara umum terdapat dalam Jurgen Habermas' Conception ${ }^{23}$ yaitu a self-organising community of free and equel citizens, coordinating their collective affairs through their common reason. Sementara itu, pengertian demokrasi secara sempit ditulis oleh Joseph Schumpeter bahwa demokrasi merupakan metode untuk memilih pemimpin. Menurut David Held $^{24}$ bahwa demokrasi harus melibatkan komunitas politik sebagai ciri utama dalam demokrasi. Sehingga dapat diartikan bahwa demokrasi tidak hanya berkaitan tentang memilih pemimpin, tetapi legitimasi kekuasaan dan kekuasaan itu dijalankan dengan melibatkan rakyat dalam kedudukannya yang setara dan bebas.

Soehino ${ }^{25}$ membedakan antara demokrasi langsung (direct democracy) dan demokrasi tidak langsung atau demokrasi perwakilan (indirect democracy) . Demokrasi langsung sebagai suatu pemerintahan oleh rakyat, dalam arti segala keputusan diambil oleh seluruh rakyat yang berkumpul pada waktu dan tempat yang sama. Hal ini hanya mungkin terjadi pada negara dengan wilayah dan jumlah warganya sedikit. Pada zaman modern, pemerintahan sudah tidak mungkin dilaksanakan lagi karena jumlah warga negara yang banyak dan wilayah negara yang luas.

Threshold adalah ambang batas atau yang diartikan dalam Kamus Besar Bahasa Indonesia (KBBI), ambang batas sebagai tingkatan batas yang masih dapat diterima atau ditoleransi. Ambang batas ini diadopsi dalam sistem pemilu, sebagai formulasi perhitungan suara dan kursi pada sistem perwakilan proporsional. Ambang batas awalnya dipergunakan dalam hal melihat tingkat kompetisi partai untuk menduduki kursi di daerah pemilihan dalam sistem Pemilu. Konsep ini mengaitkan besaran daerah pemilihan (district magnitude) dan formula perolehan kursi partai dengan metode kuota. Semakin besar besaran daerah pemilihan, maka semakin kecil persentase perolehan suara untuk mendapatkan kursi,

\footnotetext{
${ }^{23}$ Cornelia Schneider, 2000, The Constitutional Protection of Rights in Dworkin's and Harbermas' Theory of Democracy, UCL Jurisprudence Review, Vol. 7, h. 11.

${ }^{24}$ John T. Ishiyama dan Marijke Breuning, 2013, Ilmu Politik: Dalam Paradigma Abad Ke-21, (Penerjemah : Ahmad Fedyani Saifuddin), Jakarta, Kencana, h. 444.

${ }^{25}$ Soehino, 2000, Ilmu Negara, Edisi Ketiga, Cet. Ke-3, Jogjakarta, Liberty, h.240.
} 
sebaliknya jika semakin kecil besaran daerah pemilihan, maka semakin besar persentase perolehan suara untuk mendapatkan kursi.

Ambang batas bisa dipahami juga sebagai sistem perwakilan proporsional, angka dan proporsi minimum, dari jumlah pemilih untuk menjadi perwakilan atau utusan di parlemen. Istilah ambang batas juga diistilahkan dengan batas minimum, Istilah ini sering digunakan untuk mengatur ambang batas parlemen (parliamentary threshold) dan ambang batas Presiden untuk bisa ikut Pemilu (presidential threshold) ${ }^{26}$. Presidential threshold yaitu batas minimal perolehan kursi atau suara partai atau koalisi partai agar bisa mengajukan pasangan calon Presiden dan Wakil Presiden. Ambang batas ini juga dimaknai sebagai syarat perolehan suara maupun kursi bagi partai untuk bisa ikut kembali di Pemilu mendatang. Hal ini tertuang dalam UU Nomor 3 Tahun 1999 Tentang Pemilihan Umum. Pasal 39 UU No. 3 Tahun 1999 menyatakan: "Untuk dapat mengikuti Pemilihan Umum berikutnya, Partai Politik harus memiliki sebanyak 2\% (dua per seratus) dari jumlah kursi DPR atau memiliki sekurangkurangnya 3\% (tiga per seratus) jumlah kursi DPRD I atau DPRD II yang tersebar sekurangkurangnya di $1 / 2$ (setengah) jumlah propinsi dan di $1 / 2$ (setengah) jumlah kabupaten/kotamadya seluruh Indonesia berdasarkan hasil Pemilihan Umum". Ketentun ini dicantumkan kembali pada Pasal 143 ayat (1) UU Nomor 12 Tahun 2003. Inilah yang disebut electoral threshold, yaitu batas minimal perolehan kursi partai agar dapat mengikuti Pemilu berikutnya sedangkan parliamentary treshold, yakni ambang batas perolehan suara minimal parpol dalam Pemilu untuk diikutkan dalam penentuan perolehan kursi di Dewan Perwakilan Rakyat. Threshold (ambang batas) antara electoral, parliamentary dan presidential memiliki pengertian yang berbeda-beda. Electoral dan presidential adalah syarat bagi partai peserta Pemilu untuk dapat mengikuti Pemilu, sedangkan parliamentary adalah syarat untuk mendapatkan kursi di parlemen.

\section{Metode Penelitian}

Metode penelitian yang digunakan dalam menyusun disertasi ini menggunakan penelitian hukum. Penelitian hukum adalah suatu proses untuk menemukan aturan hukum, prinsip-prinsip hukum, maupun doktrin-doktrin hukum guna menjawab isu hukum yang dihadapi. Penelitian hukum dilakukan untuk menghasilkan argumentasi, teori dan konsep

\footnotetext{
${ }^{26}$ Matthew Justin Streb, 2013, Law and Election Politics: The Rules of the Game, New York, Routledge, dalam Muhammad Siddiq Armia dkk, Penghapusan Presidential Threshold Sebagai Upaya Pemuliban Hak-hak Konstitusional, 2016, Petita, Volume 1 Nomor 2, h.135.
} 
baru sebagai preskriptif dalam menyelesaikan masalah yang dihadapi, jawaban yang diharapkan di dalam penelitian hukum adalah right, appropriate, inappropriate atau wrong, dengan demikian hasil yang diperoleh di dalam penelitian hukum sudah mengandung nilai ${ }^{27}$.

Senada dengan pendapat Peter Mahmud Marzuki, Blacks Law Dictionary mengartikan Penelitian Hukum (Legal Research) sebagai: (1) The finding and assembling of authorities that bear on a question of law; (2) The field of study concerned with the effective marshaling of authorities that bear on a question of law. ${ }^{28}$ Penelitian ini lebih menenkankan pada data sekunder.

\section{Pembahasan}

Istilah Threshold dalam pemilu, mengadopsi beberapa varian threshold yang sering digunakan dalam penyelengggaraan pemilu. Varian tersebut adalah electoral threshold, parliamentary threshold, dan presidential threshold. Gotfridus Goris Seran ${ }^{29}$, mendefinisikan presidential threshold sebagai ambang batas perolehan suara yang harus diperoleh oleh partai politik dalam suatu pemilu untuk dapat mengajukan calon presiden. Penerapan presidential threshold pertama kali dirumuskan dalam Undang-Undang Nomor 23 Tahun 2003 tentang Pemilihan Umum Presiden dan Wakil Presiden, sekarang tidak berlaku lagi. Pada penyelenggaraan pemilu tahun 2019, pengaturan presidential threshold terdapat pada Pasal 222 Undang-Undang Nomor 7 Tahun 2017 Tentang Pemilihan Umum yang menyatakan bahwa: "Pasangan calon diusulkan oleh Partai Politik atau Gabungan Partai Politik Peserta Pemilu yang memenuhi persyaratan perolehan kursi paling sedikit 20\% (dua puluh persen) dari jumlah kursi DPR atau memperoleh 25\% (dua puluh lima persen) dari suara sah secara nasional pada Pemilu anggota DPR sebelumnya”.

Putusan Mahakamah Konstitusi menegaskan bahwa Pasal 222 Undang-Undang Nomor 7 Tahun 2017 Tentang Pemilihan Umum tidak bertentangan dengan ketentuan yang terdapat dalam UUD 1945. Namun berbeda dalam dissenting opinion dinyatakan bahwa dengan membaca formulasi perumusan Pasal 222 Undang-Undang Nomor 7 Tahun 2017 Tentang Pemilihan Umum, menjadi sulit dibantah bahwa pesan "tetap mendasarkan pada ketentuan UUD 1945” dalam Putusan Mahkamah Konstitusi Nomor 14/PUU-XI/2013

\footnotetext{
27 Peter Mahmud Marzuki, 2007, Penelitian Hukum, Jakarta, Kencana Prenada Media Group, h. 35.

${ }^{28} \mathrm{~W}$. Wiegand, 2001, The Reception of American Law in Eropa, The American Journal of Comparative Law, Vol. 16, No.1, Maret-April, h. 103-126.

${ }^{29}$ Seran, Gotfridus Goris, 2003. Kamus Pemilu Populer: Kosa Kata Umum, Pengalaman Indonesia dan Negara Lain, Yogyakarta: Graha Ilmu, h. 557.
} 
terang-terangan diabaikan oleh pembentuk undang-undang. Artinya, pembentuk undangundang berhenti membaca pertimbangan Mahkamah Konstitusi dalam putusan a quo hanya sampai pada kalimat syarat jumlah kursi dan jumlah suara partai politik sebagai syarat mengajukan pasangan calon presiden adalah kewenangan pembentuk undang-undang. Padahal, dengan adanya frasa “tetap mendasarkan pada ketentuan UUD 1945", pembentuk undang-undang selain memperhatikan ketentuan Pasal 6A ayat (2) UUD 1945 harus pula memperhatikan ketentuan dalam Pasal 22E ayat (1) dan ayat (2), Pasal 27 ayat (1) Pasal 28D ayat (1), dan ayat (3) UUD 1945 yang menghendaki adanya jaminan hak yang sama kepada setiap partai politik peserta pemilu mengajukan pasangan calon Presiden dan Wakil Presiden. Mahkamah Konstitusi seharusnya menempatkan atau lebih memberikan prioritas pada pemenuhan constitutional rights dari partai politik peserta pemilu dibandingkan dengan pemenuhan atas penilaian bahwa format atau constitutional design atau constitutional engineering menghendaki penyederhanaan jumlah partai politik peserta pemilu. Putusan Nomor 14/PUU-XI/2013 tentang pelaksanaan pemilihan umum serentak pada Pemilu 2019 dan pemilihan umum seterusnya didasarkan pada tiga pertimbangan utama: Pertama, untuk memperkuat rancang bangun sistem pemerintahan menurut UUD 1945 terkait dengan sistem pemerintahan presidensial dengan mekanisme saling mengawasi dan mengimbangi (checks and balances). Kedua, makna asli yang dikehendaki oleh para perumus perubahan UUD 1945 terhadap desain penyelenggaraan pemilu presiden adalah dilakukan serentak dengan pemilu legislatif. Ketiga, pelaksanaan pemilu presiden dan pemilu legislatif yang serentak sejalan dengan prinsip konstitusi yang menghendaki adanya efisiensi dalam penyelenggaraan pemerintahan dan hak warga negara untuk memilih secara cerdas.

Penetapan ambang batas jelas tidak diatur dalam UUD 1945 namun diatur dalam Undang-Undang Pemilu, agar memberikan batasan terhadap partai politik dalam mengusulkan calon Presiden dan Presiden. Ketentuan ambang batas juga tidak memiliki dasar batasan angka yang tetap dalam pengusulan calon Presiden dan Wakil Presiden sehingga pembentuk Undang-undang bisa dengan mudah mengubah batas ambang setiap pemilu sesuai dengan kepentingan partai politik. Berlakunya Undang-Undang Nomor 7 Tahun 2017 tentang Pemilihan Umum tidak berprinsip dengan rule of the game dari pemilihan umum yang adil. Hal ini tercermin kepada Pasal 222 Undang-Undang Nomor 7 Tahun 2017 tetang Pemilihan Umum. Pasal 222 tersebut secara sepihak telah menguntungkan partai politik yang pada pemilihan umum 2014 yang memiliki kursi di DPR. Padahal pada pemilihan umum tahun 2019 secara serentak juga terdapat partai baru yang 
secara konstitusi memiliki kesempatan yang sama untuk mencalonkan pasangan presiden dan wakil presiden ${ }^{30}$. Demokrasi pada dasarnya memiliki potensi untuk memberikan suatu yang baik bagi manusia terutama dalam menghadapi kekuasaan yang represif dan rakyat dipandang memiliki kesetaraan dalam politik (politcal equity). Politcal equity dapat diperoleh melalui persamaan hak dan kesempatan setiap masyarakat, kelompok atau partai politik dalam proses pemilihan umum.

Tujuan pemberian kesempatan yang sama kepada para peserta pemilihan umum untuk memenangkan pemilihan umum, yang juga berarti para peserta pemilihan umum mempunyai peluang yang sama untuk memenangkan program-programnya. Negara-negara demokrasi, pergantian pejabat pemerintahan eksekutif dan legislatif ditentukan secara langsung oleh rakyat, yaitu melalui pemilihan umum yang diselenggarakan secara periodik ${ }^{31}$.

Penggunaan ambang batas pencalonan presiden atau presidential threshold sebagai open legalpolicy, politik hukum secara sederhana dapat dirumuskan sebagai kebijakan hukum (legal policy) yang akan atau telah dilaksanakan secara nasional oleh pemerintah. pengertian ini mencakup juga terkait bagaimana politik memengaruhi hukum dengan melihat konfigurasi kekuatan yang ada dibalik pembuat serta penegakan hukum tersebut. Politik hukum sebagai media bagaimana hukum harus mengakomodasi suatu tujuan masyarakat yang dirumuskan secara politik.

Bagian yang sering dilupakan adalah bentuk partisipative democracy dalam proses pengambilan keputusan pemerintahan. Demokrasi itu esensinya adalah menyediakan pilihan, artinya demokrasi itu menyediakan pilihan kepada rakyat. Mengingat partai politik hanya bertumpuh pada satu partai politik saja untuk berkoalisi sehingga hanya melahirkan calon presiden dan wakil presiden yang diusung oleh partai politik berkuasa, artinya partai politik yang memiliki suara dan kursi di parlemen lebih banyak dari partai-partai lainnya. Partai-partai politik yang berkoalisi belum tentu mengusung calon presiden dan wakil presiden dalam pemilu presiden dan wakil presiden. Namun, hanya memberi dukungan terhadap partai penguasa dan tidak memiliki hak suara dalam mengusung calonnya sendiri berdasarkan kesepakatan yang telah ditetapkan oleh partai politik penguasa.

Akibat dari penetapan ambang batas minimal dalam pemilihan presiden dan wakil presiden karena tidak memunculkan oposisi/penyeimbang di parlemen yang dibutuhkan dalam

\footnotetext{
${ }^{30}$ Putusan Mahkamah Konstitusi Nomor 14/PUU-XI/2013 bertanggal 23 Januari 2014 mengenai Pengujian Undang-Undang Nomor 42 Tahun 2008 tentang Pemilihan Umum Presiden dan Wakil Presiden Perkara Pemilu Serentak, 2013, h. 78-82.

31 Jimly Asshiddiqie, 2006, Pengantar Imu Hukum Tata Negara Jilid II, Jakarta, Konstitusi Press, h. 176.
} 
demokrasi pasca pemilihan presiden dan wakil presiden akhirnya akan memunculkan banyak masalah dalam pembuatan undang-undang. Dalam pemilu yang demokratis sistem pemilu menyediakan beberapa pilihan yang seimbang kepada rakyat atau pemilih untuk dipilih. Kasus pemilihan presiden dengan sistem ambang batas minimal menutup kemungkinan munculnya beberapa pilihan calon presiden dan wakil presiden yang berkualitas dan amanah. Hal ini juga memicu lahirnya pemilu dinasti karena mengingat kasus pemilihan umum kepala daerah erat hubungannya dengan pemenangan presiden di pusat karena koalisi partai politik di pusat menekan partai politik di daerah.

Mengubah konsep ambang batas minimum menjadi ambang batas maksimum itu atau setidaknya tidak pada angka 20 persen sehingga partai politik dapat mengusung calon presiden dan wakil presiden yang berkualitas. Penggunaan presidential threshold yang dinyatakan konstitusional berdasarkan putusan Mahkamah Konstitusi Nomor 53/PUUXV/2017, namun Mahkamah Konstitusi juga mengatakan DPR dalam membentuk UndangUndang Pemilu terkait ambang batas tidak menggunakan dasar teori dalam penetapan angka setiap pemilu sehingga menimbulkan ketidakpastian hukum. Hal ini menjadi dasar diubahnya konsep ambang batas minimum menjadi ambang batas maksimum misalnya jika penetapan ambang batas maksimum menjadi 10\% maka partai politik yang memenuhi ambang batas $10 \%$ atau lebih tidak dapat melakukan koalisi partai sebagaimana telah dituangkan dalam UUD 1945 Pasal 6A ayat (2) yang menyatakan bahwa pasangan calon Presiden dan Wakil Presiden diusulkan partai politik atau gabungan partai politik. Ambang batas dalam presidential threshold dinilai melemahkan kaderisasi dan rekrutmen politik yang demokratis menjadi terhambat untuk mengusung kader-kadernya menjadi calon presiden dan wakil presiden. Sistem presidensial mempunyai karakter pemilu tidak bergantung pada parlemen seperti pada sistem parlementer. Sementara ambang batas pencalonan presiden sebaliknya membuat pencalonan presiden bergantung pada kekuatan yang ada di parlemen. Hal ini tidak sejalan dengan sistem presidensial. Pengalaman pemilu 2014 dan 2019, hanya melahirkan dua pasang calon presiden dan wakil presiden. Realitas politik yang saling berhadap-hadapan (head to head) tersebut dari sudut pandang realisme politik, justru menebalkan praktik koalisi politik pragmatisme. Bahkan hal yang akan mungkin terjadi jika ambang batas dinaikan maka calon Presiden dan wakil presiden yang diusung oleh partai politik hanya 1 calon sehingga harus melawan kotak kosong. 


\section{E. Penutup}

\section{Kesimpulan}

Ambang batas pencalonan Presiden dan Wakil Presiden menjadi masalah dalam proses pemilu di Indonesia. Keterlibatan masyarakat secara langsung dalam pemilihan Presiden dan Wakil Presiden melalui partai politik merupakan penggambaran demokrasi di Indonesia. Ambang batas yang ditentukan oleh badan legislatif dianggap merugikan hak partai politik dalam pengusulan calon Presiden dan Wakil Presiden. adanya ambang batas tersebut membentuk koalisi partai politik agar memenuhi ambang batas dalam pencalonan. Hal ini mengakibatkan masyarakat dalam menentukan pilihan tidak memiliki alternatif lain terhadap calon yang diusung oleh partai politik.

\section{Saran}

Seharusnya lembaga legislatif dalam membentuk undang-undang harus berdasarkan isi dari konstitusi dan tidak menghilangkan hak minoritas setiap partai politik dalam pengusulan calon Presiden dan Wakil Presiden serta asas demokrasi dalam pemilu. Ambang batas dalam pencalonan Presiden dan Wakil Presiden mengakibatkan suara masyarakat yang terwakili dari partai politik menjadi hilang karena ambang batas yang ditentukan dalam undang-undang pemilu mengakibatkan partai politik yang tidak memenuhi ambang tidak dapat mengusulkan calon Presiden dan Wakil Presiden.

\section{DAFTAR PUSTAKA}

Andi Abu Ayyub, 1987, Law in book and law in action, Jakarta Selatan, Yarsif Watampone. Brian Thompson,1997, Texbook on Constitutional and Administrative Law, Ondon, Blackstone Press Ltd.

Carla M. Zoethout et all. (eds.), 1993, Controlin Constitusional Law, Nederland, Martinus Nijhoff Publisher.

Cornelia Schneider, 2000, The Constitutional Protection of Rights in Dworkin's and Harbermas' Theory of Democracy, UCL Jurisprudence Review, Vol. 7, h. 11.

David Held, 1995, Democracy and the Global Order: From the Modern State to Cosmopolitan Governance, Stanford, Stanford University Press.

Eric Barent,1998, An Introduction to Constitutional Law, Oxford: Oxford University Press.

Franz Magnis Suseno,1991, Etika Politik, Jakarta, Gramedia.

Hans Kalsen,1992, Introduction to The Problems of Legal Theory, translated by Bonnie Litschewski Paulson and Stanley L. Paulson, Clarendon Press, Oxford.

I Dewa Gede Palguna, 2011, Pengaduan Konstitusional: Upaya Hukum Terhadap Pelanggaran HakHak Konstitusional Warga Negara (Studi Kewenangan Mabkamah Konstitusi Indonesia dalam Perspektif Perbandingan), Disertasi, Jakarta, Program Doktor Ilmu Hukum Universitas Indonesia. 
Jawahir Thontowi, 2002, Islam Politik dan Hukum: Esai-esai Ilmiah untuk pembaharuan, Cetakan I, Yogyakarta, Madyan Press.

Jimly Assiddiqie-I, 2010, Pengantar Ilmu Hukum Tata Negara, Jakarta, Raja Grafindo utama. Jimly Asshiddiqie, 2006, Pengantar Ilmu Hukum Tata Negara Jilid II, Jakarta, Konstitusi Press. Jimly Assidiqie, 2011, Konstitusi dan Konstitusionalisme Indonesia, Jakarta, Sinar Grafika, h. 128. John T. Ishiyama dan Marijke Breuning, 2013, Ilmu Politik: Dalam Paradigma Abad Ke-21, (Penerjemah : Ahmad Fedyani Saifuddin), Jakarta, Kencana.

John Rawls, 2011, A Theory of Justice Teori Keadilan, Yogyakarta, Pustaka Pelajar.

KC Wheare, 1996, Modern Constitution, London, Oxford University Press.

Larry and Richard Gunther, 2001, Political Parties and Democracy, USA, The Johns Hopkins University Press.

Matthew Justin Streb, 2013, Law and Election Politics: The Rules of the Game, New York, Routledge, dalam Muhammad Siddiq Armia dkk, Penghapusan Presidential Threshold Sebagai Upaya Pemulihan Hak-hak Konstitusional, 2016, Petita, Volume 1 Nomor 2, h.135.

Mahfud MD, 2003, Demokrasi dan Konstitusi di Indonesia, Jakarta, Rineka Cipta.

Mahfud MD, 2017, Politik Hukum di Indonesia, Jakarta, Rajawali Pers.

Muhamad Ali Safa'at, 2011, Pembubaran Partai Politik, Jakarta, Rajawali Pers.

Ni'matul Huda, 2014, Perkembangan Hukum Tata Negara, Yogyakarta, FH.UII Press.

Peter Mahmud Marzuki, 2007, Penelitian Hukum, Jakarta, Kencana Prenada Media Group.

Ramlan Surbakti, 2014, Pemilu Berintegritas dan Adil, Harian Kompas edisi 14 Februari, h. 6.

Seran, Gotfridus Goris, 2003. Kamus Pemilu Populer: Kosa Kata Umum, Pengalaman Indonesia dan Negara Lain, Yogyakarta: Graha Ilmu.

Soehino, 2000, Ilmu Negara, Edisi Ketiga, Cet. Ke-3, Jogjakarta, Liberty.

Sri Soemantri M, 2014, Hukum Tata Negara Indonesia pemikiran dan Pandangan, Bandung, Remaja Rosdakarya.

Taufiqurrahman Syahuri, 2011, Tafsir Konstitusi Berbagai Aspek. Hukum, Jakarta, Kencana Prenada Media Group.

W. Wiegand, 2001, The Reception of American Law in Eropa, The American Journal of Comparative Law, Vol. 16, No.1, Maret-April, Pp. 103-126. 